[Vicino Oriente XX (2016), pp. 29-48]

\title{
EARLY ISLAMIC MODELS OF URBAN AND RURAL SETTLEMENTS IN THE SOUTH BILĀD AL-SHĀM
}

\author{
Antonio Carfì - Indipendent Scholar
}

\begin{abstract}
This contribute aims at an integration between archaeological remains (artefacts and features) and historical sources to shed new light on the settlement system in the southern area of the SyrianPalestinian region at the beginning of the Islamic period. The intense occupation of the area demonstrates a strong urban and rural organization and also highlights the importance of Ayla as a commercial gateway (junction) to the Red Sea.
\end{abstract}

Keywords: Early Islamic settlements; Ayla; Jordan; Red Sea; maritime trade

\section{INTRODUCTION}

Studies on the nature of the settlements of the Early Islamic period in the southern area of Bilād al-Shām have mostly focused on the growth of the settlements over time rather than on developing a model to explain how the rural communities were linked to the urbanization of the area.

The settlements analysed here are Ayla, Humayma and the various sites of the Karak plateau (especially Șughar and Shuqayra), which is the area covered by the narrow strip of territory between the eastern shore of the Dead Sea and the steppic area bordering the Syrian-Arabian desert, now divided into Jordan, Israel and Palestine. From a topographical point of view this area (also known as the Wādī 'Araba) is divided into a southern and a northern region by the canyon of the Wādī Mūjib, whose source is close to the Roman military camp of Lajjūn, or Legio. Other important water courses are the Wādī Hasa, which delimits the southern boundary; the Wādī Wālā, an eastern tributary of the Mūjib; the Wādī Zarqā Ma'in and, on the southern edge facing the coast, the Wādī Karak and Wadi Numeīra.

The majority of the settlements excavated in this area show similar settlement and layout models. The first topographical map of the region was made by Alois Musil. ${ }^{1}$ Further important information has come from investigations at numerous sites, even if only some of the results have been published as monographs. We can mention the archaeological investigations by B. McDonald, A.M. Smith II, M. Stevens and T.M. Niemi, by U. Avner and J. Magness and, finally, by S.T. Parker, published from the $1980 \mathrm{~s} \mathrm{on}^{2}$ as well as the

\author{
Musil 1934 \\ McDonald 1980; Smith - Stevens - Niemi 1997; Avner - Magness 1998; Parker 2006.
}


excavations carried out in the town of Humayma, ${ }^{3}$ on the Karak plateau, ${ }^{4}$ and at Ayla and its surrounding area ${ }^{5}$ (fig. 1).

Thanks to the progress made by recent studies and in particular the excavations carried out by the Universities of Chicago and Copenhagen at Ayla, by the University of Victoria at Humayma and by the University of Mu'ta (Jordan) on the Karak plateau, we have a substantially more complete picture of the urban and rural settlements across a significant part of this area.

\section{AYLA}

The urban settlement dating from the Islamic period was discovered in 1985 by Donald Whitcomb of the Oriental Institute of Chicago University; between 1986 and 1995 the town underwent excavations which allowed clarifying the extent of the Early Islamic occupation ${ }^{6}$ (fig 2a). Whitcomb dated the foundations of the town walls to $650 \mathrm{CE}$, under the caliphate of 'Uthmān ibn 'Affān. ${ }^{7}$ In 2000 S.T. Parker carried out some excavations close to the walls of the residential area to find its foundations and possible stratigraphic contexts, and he confirmed that their first phase dated to the $7^{\text {th }}$ century. ${ }^{8}$

A co-operation between the Jordanian Department of Antiquities, the University of Copenhagen and the University of Chicago has led to renewed study and research into the Islamic Red Sea port by the Aylah Archaeological Project (AAP), which began this work in 2011 and brought to light five rooms (IM 1-5) in the south-west quadrant of the site (fig. 2b). ${ }^{9}$

The initial phase of the Islamic conquest was made more effective by two institutional processes: the take-over of local communities by legal settlements (sulh) and the

3 Oleson 2003; 2010

4 Brown 1991; Walmsley - Karsgaard - Grey 1999

5 The results have been published in articles and reports. For Ayla's history and excavations see Whitcomb 2000; 2006a; 2006b; 2009; 2010; Parker 2003; 2009 (fig. 3b); de Meulemeester - Pringle 2006; Damgaard 2013a; Damgaard - Jennings 2013.

6 Many articles on the results of the excavations have been published, for the most recent see Whitcomb 2006a; 2007; 2009.

7 As for the date of the settlement and the archaeological evidences of the urban area that go back to the Umayyad period, see Whitcomb 1989; see also Walmsley 2007, 95. Knauf and Brooker suggested (1988) that the walls of the Islamic city actually correspond to the perimeter of the Roman legionary castrum of the Legio $X$ Fretensis, and that they were reutilised at a later stage; Whitcomb rejected this reading (1990). Later on, even P. Wheatley (2001, 290) wrote about the relationship between the first stage of the urban area and the legionary castrum, based on the similarity with the Roman installations built after the reign of Diocletian.

8 Parker 2002, 421.

9 The excavations opened a diagnostic unit of $10 \times 10 \mathrm{~m}$ in the south-west quadrant of the town and another one of $5 \times 2 \mathrm{~m}$ along the outer part of the walls flanking the Egypt Gate (Damgaard - Jennings 2013). The two areas excavated by the Danish mission focused both on the nature and the function of the south-west quadrant of the urban area - particularly on the relationship with the structures excavated by Whitcomb outside the southern walls - and on the regular layout set up in the first building phase, in order to verify if such a layout was respected during the later phases. 
establishment of effective military garrisons (amșār) in the most important strategic locations, often near already existing towns. ${ }^{10}$

Ayla (and the nearby Byzantine town of Ailana) is a typical example of a garrison town or mișr in this region. It was planned and laid out following an orthogonal street plan, including four main gates linked by two principal axes, with a tetrapylon most likely set at the intersection of the latter. The principles of symmetry and axiality, which formed the basis for the development of this first urban settlement, suggest a return to the bank of knowledge inherited from the Romano-Byzantine world. In successive development phases, this plan was partly abandoned in favour of one which seemed to base itself more on a continual transformation of the urban layout.

In the second half of the $8^{\text {th }}$ century, the settlement of Ayla was significantly rebuilt following the earthquake of 748/49 CE and the contemporaneous Abbasid revolution. The congregational mosque and a new $s \bar{u} q$ were built, the latter located on the outer side of the southern wall facing the beach. ${ }^{11}$ The pottery from this phase, both glazed and unglazed, suggests new trading links with Iraq, Iran and Egypt. ${ }^{12}$ The building work suggested a marked increase in both the economy and the population. ${ }^{13}$ However it also seems significant that the works were mostly carried out along the guidelines laid down by the original plan. In the southern and western sectors, buildings grew up on the outer sides of the town walls. Some of them had doors opening into the towers along the city walls, completely nullifying their military function.

10 This stage of the Islamic conquest had rather considerable consequences on the territory: rural fields were strengthened and a large part of the income from the North African and Oriental conquests was used for a territorial occupation resulting in an important boost to the economy by stimulating the local demand for goods and services (Bacharach 1996, 35-36; Petersen 2005; Schick 1998, 76). According to Kennedy (1992, 294; 2001, 187-190; 2008, 93) such economic and social growth depends on the fact that in the Bilād al-Shām a large part of the new elites owned urban or out-of-town properties, while in Iraq and Egypt the Muslim town settlers depended directly on the state. Only when the Umayyad dynasty was fully established was a programmatic policy of the territorial organization of the country attempted; when the capital was moved to Damascus the town became the fulcrum of the caliphate. Under the caliphate of 'Abd al-Malik the administrative system and the bureaucracy ( $(\bar{\imath} w \bar{a} n)$ were strongly centralized and reorganized from the inside. The grid plan, which was already efficient during the Roman and Byzantine age, was resumed through the bari $d$, a system connecting the main centres of the region. The barid organization was very similar to that of the Roman stationes (Hawting 2000, 86-87); the milestones of 'Abd al-Malik constitute archaeological evidence of this fact (see Sharon 1966; Elad 1999). It is useful to stress the economic and social importance of the yearly pilgrimage to Mecca by people coming from a large part of the Islamic world (Damgaard 2009, 92). During this century a crucial role was also played by the mawalī, who occupied important positions as bureaucrats, notables, but also land-owners and farmers. Administrative responsibilities were delegated to half tribal confederations under the authority of the provincial government (Northedge 1992, 51; Schick 1997, 76; Hawting 2000, 35; Walmsley 2000, 327).

11 The plan of the mosque shares some features with coeval sites such as Sīrāf (Iran), Banbhore (Sind) and Bilād in the southern part of present-day Oman (Whitcomb 1995, 62).

12 Ghawanmeh 1992, 55; Whitcomb 1994b.

13 This tendency is also confirmed by Thomas Parker's discovery of Umayyad and Abbasid buildings during the works for the Roman Aqaba Project; these structures included housing units in the areas A, K and L, situated outside the walls, in the south and north-west areas (Parker 2009). 
This pattern of occupation beyond the walls confirms that the northern part of the town extended into the areas around and included houses, shops and streets (at present a large part of the western side of the suburb is occupied by Hotel Mövenpick). Two large pottery kilns, whose original phase can be dated to the $5^{\text {th }}$ century CE, are located only a short distance from the walls of Ayla and were used for the production of the typical Aqaba Amphora between the $7^{\text {th }}$ and $9^{\text {th }}$ centuries. ${ }^{14}$

At the beginning of the $9^{\text {th }}$ century there was a revolt in Ayla against the kharāj, a sort of property tax, usually levied on non-Muslims. The sources suggest that under the Abbasid caliphate this region was ruled harshly and punitive taxation was frequently levied. ${ }^{15}$

Between the $9^{\text {th }}$ and $10^{\text {th }}$ centuries Ayla and Ailana became one town.

The southern part of the district, which currently contains a fort dating from the Mameluke era, includes levels and structures dating to the $8^{\text {th }}$ century, which were in use until the $11^{\text {th }}$ century. These consist of underground water channels linked by wells and embankments which formed a sort of agricultural terracing system. ${ }^{16}$ This finding makes it possible to hypothesize a peripheral settlement to the south involved in agricultural production, with a system for the storage and distribution of water. In the valleys surrounding Ayla to the north and west, investigations revealed that the whole area was extensively used for a variety of productive processes (fig. 3a). ${ }^{17}$ It is important to recall the discovery of Early Islamic pottery at the site of Jabāl Umm Nusaīla, which was also a centre of agricultural production, halfway between Ayla and $\mathrm{Ma}$ 'an, with a water storage system suitable for an area of approximately $500 \times 250$ metres. The entire area was not intended for agriculture alone, as pits for glass grinding and a copper mine have been discovered, which suggest that the area was involved in the working of raw and semiprocessed materials. ${ }^{18}$

Evidence was found from the late $8^{\text {th }}$ century of the expansion of methods of production, transport and trade and a major reorganisation and reorientation of the trade routes, which also affected part of the urban landscape.

14 Melkawi - Khairieh - Whitcomb 1994. This type of amphora was discovered in Berenike and Axum, and during an underwater excavation of a wreck off the Eritrean coast (Wilding 1989; Hayes 1996; Pedersen 2000). Damgaard reconstructed part of the commercial landscape of the late $8^{\text {th }}$ century in the Red Sea through an archaeometric study of the corpus of 'Aqaba pottery, discovered in the Yemeni site of Zafār (Damgaard 2013b).

15 The revolt was headed by Abū 'l-Nidā and was promptly suppressed by the troops of caliph Hārūn al-Rashīd. It has been hinted that there were two other revolts under caliph al-Wāthiq (Gil 1997, 292-295; Kennedy 2004, 149-154).

16 de Meulemeester - Pringle 2004; 2005; 2006.

17 The data that emerged in the Nineties following surveys of the southern zone of the Negev desert and Wādi 'Araba, respectively made by A.M. Smith II, M. Stevens and T.M. Niemi (1997) (fig. 3c), and U. Avner and J. Magness (1998) are essential for understanding Ayla's hinterland. These rural settlements used a sophisticated system of irrigation, also characterized by the introduction of new crops and industrial activities linked to copper and gold mines, and even quarries.

18 Avner - Magness 1998, 47. 
This continuity of occupation from the Byzantine through to the Islamic era is typical of other areas in the southern part of modern Jordan, such as Humayma and the settlements of the Karak plateau.

\section{HUMAYMA}

The archaeological site of Humayma (an Arabic diminutive of hummah, "white") is located about $75 \mathrm{~km}$ north of Ayla, exactly halfway between the modern 'Aqaba and Ma'an. Known as Avara in classical sources, it was one of the major centres in the area during the Nabatean and Roman periods. The most recent researches have been conducted by John Peter Oleson from the University of Victoria, Canada. ${ }^{19} \mathrm{He}$ has found evidence for continual occupation up to the $11^{\text {th }}$ century. ${ }^{20}$ During the Roman period the town maintained its importance due to its position along the Via Traiana Nova. The foundation of the city has been dated to the reign of the Nabatean King Haretha III and the city played an important part in the trade of the Nabatean state. ${ }^{21}$

The castrum, built on a rectangular plan, measures $208 \times 148 \mathrm{~m}$ and has a 3 metre-thick curtain wall with 24 projecting towers, all internally accessible (fig. 4b). In comparison with the other Roman castra of Udruh and Lajjūn, ${ }^{22}$ it is the closest to the town of Ayla. All these settlements share a very similar layout since they follow the same model of symmetry and axiality and their walls have semi-elliptical projecting towers, apart from the square towers of Humayma.

At the end of the $7^{\text {th }}$ century the Abbasid family, who boasted of direct descent from the Prophet Muhammed through Hāshim, appeared on the Syrian-Palestinian scene acquiring land tenure around Humayma. ${ }^{23}$ According to tradition, the caliph 'Abd al-Malik advised a member of the Quraysh clan, 'Alī ibn 'Abd Allāh ibn 'Abbās ibn 'Abd al-Muțtalib, a paternal uncle of the Prophet, to move to the region of al-Balqa' because of its position between Damascus and Hijāz. In 687 that son of the merchant from Mecca decided to take his family to live in Hiumayma, where he built a qașr and a mosque to the south of the

19 Oleson 2003; Savane - Zamora - Keller 2003.

20 In the mid-Eighties, John Eadie found sherds of Umayyad pottery by exploring the area around Humayma (Eadie 1984, 220). Similar findings were also made at a later stage, during the works of Clark's Limes Desert Survey (Clark 1987, 128-135), confirming a different pottery horizon for southern Jordan (Whitcomb 2000)

21 Fakhiry 2003.

22 An occupation phase during the Islamic period is attested in Lajjūn, precisely in the north quadrant of the urban area, showing rectangular rooms around a central courtyard. Among them an Early Islamic building has a square plan of $18 \mathrm{~m}$ per side, formed by a rectangular courtyard with eight rooms all around, that was subsequently transformed into a caravanserai (de Meulemeester 2000, 196-197).

23 The sources state that 'Abd Allāh b. al-'Abbās ordered the family to move so as to secure a more direct contact with the centre of Umayyad power. Moreover the Abbasid family was kin to Abū Hāshim, the son of Muhammad ibn al-Hanafiyya, who participated in the second civil war organized by Mukhtar (Hawting 2000, 132-133). The main Arab sources on Humayma are: the $10^{\text {th }}$ century anonymous author of the Akhbār alDawlah al- 'Abbāsiyya (1971); al-Balādhurī (1978); al-Ṭabarī (1879-1901); al-Ya qūbī (1892); Salah - Azzawi (1997, 356). 
Byzantine settlement and built up a network of clients among the local population. ${ }^{24}$ alMuțțalib welcomed in the qașr pilgrims heading for Mecca and Medina and built around his palace a series of gardens or orchards containing 500 trees, under which daily prayers would be said. ${ }^{25}$ This, along with Kūfa and the Khurāsān, was one of the sites where they planned the revolution that brought down the Umayyad dynasty.

Ya 'qūbī identified it as a place frequented and populated by the client groups of Banū Hashīm, i.e. the Abbasids. ${ }^{26}$ al-Baladhūrī asserted that everyone travelling down from Syria to the Hijāz Province, or back, had to pass through Humayma and would be very tempted to stay there awhile. ${ }^{27}$ The sources provide us with quite a good picture of the ruling class at Humayma, but tell us little or nothing about the town. Oleson's excavations brought to light numerous structures, including domestic buildings from the Nabatean and Roman periods, a castrum and a bathhouse from the Roman era, five Byzantine churches (one of which, a monoapsidal church built on top of a Nabatean necropolis, was turned into a residential complex in the Early Islamic period) and an aqueduct, $26.05 \mathrm{~km}$ long, which was fed by three natural springs from Rās al-Naqab, carrying water to an open cistern positioned at the southern end of the castrum. ${ }^{28}$

It is quite likely that the arrival of the Abbasid family in Humayma led to the growth of the population, detectable by an increase in the number of houses built around the Roman fort containing pottery dating to this Early Islamic period. ${ }^{29}$

Building F103 (the qașr), in the south-east part of the urban area, has been identified as the residence of the Abbasid family, dating to the middle of the $8^{\text {th }}$ century. ${ }^{30}$ This building has a rectangular plan $(61 \times 50 \mathrm{~m})$ with a series of rooms surrounding a central courtyard. The qașr was constructed on an earlier structure, detectable only by a series of dividing walls in the northern area (fig. 4c). The entrance, about $21 \mathrm{~m}$ wide, is on the east side. From there one entered the courtyard, which had a portico along the east side. A dirham, struck in $115 \mathrm{H} / 733-34$ by al-Wāsiț, was found at the entrance to the qașr and is evidence of the movement of people who were, according to the sources, present in the town just before the

24 'Alī ibn 'Abd Allāh ibn 'Abbās ibn 'Abd al-Muțțalib, the son of a rich merchant who during the first years of Islam protected Muhammad while he was in Mecca, had about 22 sons; one of them, Muhammad Ibn 'Alī Ibn 'Abdullāh Ibn 'Abbās, was one of the founders of the Abbasid party during the revolt against the Umayyad caliphate in 750. In fact in 749 the Abbasid family abandoned the town and moved to Kūfa, the first seat of the new caliphate. The first two caliphs of this dynasty, Abū '1-'Abbās al-Saffāh and Abū Ja' far 'Abd Allāh ibn Muhammad al-Manșūr, were both born in Ḥumayma (see Lapidus 2002, 54 ff.).

25 Akhbār al-Dawlah al- 'Abbāsiyya 1971, 154; Salah - Azzawi 1997, 355.

26 al-Ya qūbī 1892, 326.

27 al-Balādhurī 1978, 53-55

28 The construction of an efficient system of aqueducts and cisterns (a total of 11) should be attributed to the Nabateans. The main course of the aqueduct, $18.9 \mathrm{~km}$ long, connected the spring of 'Ayn al-Qana (1425 m a.s.l.) to the main water reservoir of the town (995 $\mathrm{m}$ a.s.l.). A secondary branch (7.6 km) maintained the water supply from the springs of 'Ayn al-Shara and 'Ayn al-Jamām. This supply was partially enlarged under Roman dominion, with the creation of a new cistern, presumably to supply the fort built there (Eadie - Oleson 1986).

29 Schick 2007, 352

30 Oleson 2003, 55-56. 
Abbasid revolution. The qașr still remained in use after the second half of the $8^{\text {th }}$ century and more building took place there in Ottoman times. ${ }^{31}$

The central room of the western portico is worthy of note. ${ }^{32}$ Its impressive appearance led to the belief that this was the place where 'Abdullāh bin al- 'Abbās greeted the members of the Abbasid family. A passage of the Akhbār al-Dawla al-'Abbāsiyya describes this building: when Bukayr bin Māhān paid his first visit to Muhammad b. 'Alī, he entered a wide open area or courtyard (rahbah) around which the apartments (manzil) of the family members were gathered. Building F103 continued to be used subsequently, even though the town was gradually being depopulated.

Two mosques are situated to the south-east of the qașr and they are among the smallest mosques of the Early Islamic period in Bilād al-Shām. One was built on a square plan (5.75 $\times 5.60 \mathrm{~m}$ ) and, according to pottery fragments, dated to the $8^{\text {th }}$ century. The entrance is on the north; inside the space is divided by a transversal arch and the prayer hall is flanked by two washing rooms. On the qibli wall is a semi-elliptical mi hrāab. The very limited space for the prayer hall suggests that it may have been for private use, reserved for the adult males of the Abbasid family. ${ }^{33}$ South-west from the qibli wall another rectangular room identified as belonging to the second mosque was added at a later date and its mihrāab is semi-elliptical too. No other remains of mosques have been identified at Humayma, which might suggest that the town had few Muslim inhabitants apart from the Abbasid family. ${ }^{34}$

Building F102 was identified as a church built during the second half of the $7^{\text {th }}$ century. ${ }^{35}$

This site was continuously occupied even after the Abbasid revolution, when the family had finally moved away to Iraq. However, the number of occupied dwellings fell and some were already abandoned by the end of the $8^{\text {th }}$ century. Al-Ya 'qūbī and Yāqūt al-Hamawī record Humayma in their lists mainly for being occupied by the Abbasid family. ${ }^{36}$ It is worth noting that the Abbasid family completely forgot Humayma after gaining power; no building work of any significance took place there after the middle of the $8^{\text {th }}$ century. AlHarawi (first half of the $13^{\text {th }}$ century), described it as "a village where Muhammad ibn 'Alī ibn 'Abdullāh ibn 'Abbās once lived [...]". ${ }^{37}$

31 Oleson 2003, 55-60.

32 Fragments of an ivory panel portraying the profile of a soldier from the Abbasid period were found there. This object may have belonged to someone from these regions who was in contact with the Abbasid family (Oleson 2001, 578). On the basis of a stylistic analysis Rebecca M. Foote suggested the artefact was of eastern origin, probably Iran or Central Asia (Foote 2007, 461-463). Parallels can be found with the ivory panels discovered in Ayla (see Whitcomb 1994a, 28-30).

33 Oleson 2003, 56.

34 Ibidem. Schick (1995) states that Christians were granted privileged status during the Abbasid occupation of the town.

35 Churches remained intact even though some of them were used as houses during the Umayyad period. There is no evidence that these Byzantine buildings were used as mosques ('Amr - Schick 2001).

36 al-Ya qūbī 1892, 114; Yāqūt al-Ḥamawī 1866-1873, II, 342-343.

37 al-Harawī 1953, 17. 


\section{KARAK PLATEAU}

The Karak plateau is situated at the southern tip of the Transjordan plateau, in the central area of Jordan, to the south of the Dead Sea at an elevation of c. $900 \mathrm{~m}$ above sea level. The region is bordered on the west by the Ghawr plain and to the north by the Yarmuk River.

Investigations carried out by the Karak Resources Project Survey team identified a continuous occupation of the region dating from the Palaeolithic up to the modern era. ${ }^{38} \mathrm{~A}$ pattern of small and medium-sized settlements has been attributed to the Islamic period, probably because the fertility of the soil and sufficient rainfall have permitted the cultivation of various cereals and olives since ancient times. ${ }^{39}$ In the $12^{\text {th }}$ century William of Tyre confirmed the fertility and prosperity of this area based on agricultural production. ${ }^{40}$

In the Islamic period it was a district of the jūnd Dimashq, called al-Sharāt, ${ }^{41}$ including a number of smaller settlements. We mention two examples, Șughar and Shuqayra, the latter in particular offering a more detailed archaeological portrait than other sites on the plateau.

Sughar is a town situated on the southern shores of the Dead Sea. The Arab geographer Dimashqi (d. ca 1327) included it in his list of towns of the Ghawr region and noted that the entire area around the settlement was similar to Iraq due to the abundance of water and land under cultivation. ${ }^{42}$ Even Muqaddasī described it as a town of wide-ranging economic activity and compares it to a small Boṣrā. ${ }^{43}$ The settlement is mostly known from sources, as only the archaeological investigations of the early 2000s found evidence of either buildings with foundations connected to pottery sherds of the Umayyad and Abbasid dynasties, or of an agricultural complex at Khirbat al-Shaykh 'Īsā. ${ }^{44}$ Nothing more can be said about the town complex without a more substantial excavation, but given its importance, as attested by the sources, it is probable that during the $7^{\text {th }}$ and $8^{\text {th }}$ centuries Șughar was a northern "trading rival” to Ayla.

Shuqayra is close to Khirbat al-Qusba, about $15 \mathrm{~km}$ to the south-east of Mu'ta on the Karak plateau. In the first half of the $10^{\text {th }}$ century Musil and N. Glueck identified some

38 Brown 1991; Walmsley - Karsgaard - Grey 1999.

39 The rainfall reaches an average of $300 \mathrm{~mm}$ per year, while it is much less on the shores of the Dead Sea and in the Jordan Valley, where it rarely exceeds $100 \mathrm{~mm}$. Another important meteorological phenomenon is the sharqiya, the hot wind from the East that blows for few days but at regular intervals. The production of cereals, olives and legumes, especially lentils and chickpeas, requires a precise quantity of rainfall of $300 \mathrm{~mm}$. In the period in which the Arab-Muslims settled, the region held a particular record in the production of sugar cane (Benedettucci 2011; Milwright 2008, 9).

40 Willelmi Tyrensis 1976, 506-507.

41 The capital of this district is often identified with Udrūh, and at other times with Șughar or Ayla (Johns 1995, 10-11).

42 Al-Dimashqī 1866, 211.

43 In the Geniza documents Sughar is described as a market station between the Syrian-Palestinian area and India (Amar 1998, 5).

44 Jones et al. 2000. 
ruins in the area of Khirbat al-Qusba ${ }^{45}$ and a later survey carried out by M. Miller revealed some pottery fragments datable to the Early Islamic period. ${ }^{46}$ The name Shuqayra comes from the Arabic "little blonde girl", referring to the yellow-red colouring of the soil.

More information about the Islamic settlement came from the excavations led by the University of Mu'ta, which started in 2002. During six seasons of digging, over four different areas of the site, traces were found of a wide building constructed from blocks of squared-off limestone (fig. 4d). ${ }^{47}$ Its plan shows similarities with the vestibule of the Umayyad castle of Khirbat al-Minya. ${ }^{48}$ In 2006 a trench uncovered the foundations of the vestibule, allowing the first building installation to be dated to the Umayyad period. The complete chronology of the building has been established on the pottery evidence, which shows at least three different phases: a first "Nabatean" phase, from the $1^{\text {st }}$ century CE; a second "Umayyad-Abbasid" phase ( $8^{\text {th }}$ century); a third "Ayyubid-Mameluke-Ottoman" phase from the $12^{\text {th }}$ to the $16^{\text {th }}$ century. The second phase is the most represented with around $80 \%$ of the discovered fragments. ${ }^{49}$ A doorway $1.8 \mathrm{~m}$ wide opened onto the vestibule, a rectangular area $(8.40 \times 4.50 \mathrm{~m})$ leading to a paved courtyard. There were nine rectangular rooms to the north and south of the doorway, on the east side. The southern side of the courtyard provided access to a sort of corridor which probably had a hypostyle roof, inferred from the discovery of three column bases. Even further to the south is Building C, which had a large rectangular room paved by a mosaic with geometric and floral motifs. This is the first mosaic found on the Karak plateau, extending over more than $160 \mathrm{~m}^{2}$ and dating to the Early Islamic period. It may have been the audience hall of the whole complex. ${ }^{50}$

The entire settlement had a complex water supply involving underground channels and a cistern some 250 m away. ${ }^{51}$

Evidence has been found on this plateau of residential settlements from the Umayyad and Abbasid periods at al-Lisān and Ma ān, to the east of the Dead Sea, south of the Wādi Mūjib. ${ }^{52}$ The same type of settlement has been found at Khirbat Abū Suwwāna and 'Ayn 'Aneva to the west of the Dead Sea. ${ }^{53}$ They all feature more or less rectangular rooms surrounding a courtyard, with walls mostly of local stone. The spatial organization of these villages reveals a typical construction method used in settlements and farms that grew up in

45 Glueck 1939, 63.

46 Miller 1991, 161.

47 Shdaifat - Tatwne - Ben Badhann 2006; Shdaifat - Ben Badhann 2008.

48 Creswell - Allan 1989, 92-97.

49 These three phases correspond to the stratigraphic sequence recognized in the site; unfortunately, from an architectural perspective, no absolute chronological sequence has been ascertained. The discovery of an Umayyad coin and an ostrakon with a Kufic inscription is attributed to the second phase (Shdaifat - Tatwne Ben Badhann 2006; Shdaifat - Ben Badhann 2008, 187-188).

50 Shdaifat - Ben Badhann 2008, 186.

51 Ibidem.

52 Discovered by King in the early Eighties (King 1985, 41-45).

53 Found during Jodi Magness's surveys west of Jerusalem in 1991 (Magness 2003, 11-23; see also Genequand 2006). 
the Umayyad period following the settlement of nomadic tribes and the new exploitation of the land for agricultural production. ${ }^{54}$

\section{CONCLUSIONS}

As far as Ayla is concerned, it is possible to observe that in addition to rural expansion the $8^{\text {th }}$ century saw the growth of towns and changes to their layouts. The way the space was organized suggests that a much larger area was involved than just that enclosed by the perimeter walls. Ayla continued to be the fulcrum of the entire southern region, in both commercial and administrative terms (fig. 4a).

Thus between the $7^{\text {th }}$ and $8^{\text {th }}$ centuries over the whole area it was possible to find occupied land and the subsequent development of agricultural production which, combined with trade, formed the backbone of the economic activities of a population spread out across the territories between the towns discussed. The arrangement of the towns and the countryside was not disrupted by the Islamic conquest which, nonetheless, defined a new urban and rural relationship already in transition. This introduced a new settlement model, characterized by close interaction between town and countryside; towns thus acted as trade centres for local products. ${ }^{55}$

The towns were linked by these "farms/producers" in a network of settlements including a major part of the Wādī 'Araba and the Negev desert and the urban realities of the Karak plateau. ${ }^{56}$

\section{REFERENCES}

AMAR, Z.

1998 The Production of Salt and Sulphur from the Dead Sea Region in the Tenth Century according to at-Tamimi: Palestine Exploration Quarterly 130 (1998), pp. 3-7.

'AMR, K. - SCHICK, R.

2001 The Pottery of Humeima: The Closed Corpus from the Lower Church: E. VILLENEuvE P.M. WATSON (eds.), La céramique byzantine et proto-islamique en Syrie-Jordanie (IVeVIII siècles apr. J.-C.). Actes du colloque tenu à Amman les 3, 4 et 5 décembre 1994, Beirut 2001, pp. 305-313.

AvNer, U. - MAgness, J.

1998 Early Islamic Settlements in the Southern Negev: Bulletin of the American School of Oriental Research 310 (1998), pp. 39-57.

54 Magness 2003, 23.

55 The economic relationship between the inhabitants of the Gulf coast and the northern hinterland is crucial to understand the system of settlements that arose during the Islamic period.

56 Other surveys around the Humayma area would be necessary to verify the presence of agricultural systems from an Early Islamic period similar to those of other areas of the territory (Avner - Magness 1998, 39). The role played by the capital of $j \bar{u} n d$, al-Ramla, is still not clear. 
BACHARACH, J.

1996 Marwanid Umayyad Building Activities: Speculations on Patronage: Muqarnas XIII (1996), pp. 27-44.

AL-BALĀDHURİ

1978 Ansāb al-Ashrāf, III, transl. 'Abd al-'Azīz ad-Dūrī, Bibliotheca Islamica, Wiesbaden 1978.

BENEDETTUCCI, F.

2011 La geografia di Moab tra fonti letterarie, epigrafia ed archeologia (https://www.academia.edu/1649825/La_geografia_di_Moab_tra_fonti_letterarie_epigrafi a_ed_archeologia).

BROWN, R.

1991 Ceramics from the Kerak Plateau: J.M. MiLLER (ed.), Archaeological Survey of the Kerak Plateau, Atlanta 1991.

CLARK, V.A.

1987 The Desert Survey: S.T. PARKER (ed.), The Roman Frontier in Jordan, Oxford 1987.

CRESWELl, K.A.C. - J.W. AllaN

1989 A Short Account of Early Muslim Architecture, Aldershot 1989.

DAMGAARD, K.

2009 A Palestinian Red Sea Port on the Egyptian Road to Arabia: Early Islamic Aqaba and its Many Hinterlands: L.K. Blue - J. CoOPeR - J. Whitewright - R. ThOMAS (eds.), Connected Hinterlands. Proceedings of Red Sea Project IV, Held at the University of Southampton, September 2008, Oxford 2009, pp. 85-97.

2013a Between Castrum and Medina. A preliminary note on spatial organisation and urban development in Medieval Aqaba: U. Vermeulen - K. D’Hulster (eds.), Egypt and Syria in the Fatimid, Ayyubid and Mamluk Eras. Proceedings of the 11th, 12th and 13th International Colloquium organized at the Katholieke Universiteit Leuven in May 2001, 2002 and 2003, Leuven 2013, pp. 39-65.

2013b Finding Fatimid Jordan: A Reinterpretation of Aylah's 'Fatimid Residence': U. Vermeulen - K. D’Hulster (eds.), Egypt and Syria in the Fatimid, Ayyubid and Mamluk Eras. Proceedings of the 11th, 12th and 13th International Colloquium organized at the Katholieke Universiteit Leuven in May 2001, 2002 and 2003, Leuven 2013, pp. 67-97.

DAMGAARD, K. - JENNINGS, M.

2013 Once More unto the Beach: New Archaeological Research into Jordan’s Port on China Sea: Annual of the Department of Antiquities in Jordan 57 (2013), pp. 477-502.

DE MEUlemeEster, $\mathrm{J}$.

2000 Recherches archéologiques sur le site de Lehun (Jordanie), Chronique: Archéologie Islamique X (2000), pp. 196-197.

De Meulemeester, J - Pringle, D.

2004 The 'Aqaba Castle Project 2003: Newsletter of the Council for British Research in the Levant (2004), pp. 26-27.

2005 The 'Aqaba Castle Project 2004-5: Newsletter of the Council for British Research in the Levant (2005), p. 42.

2006 The 'Aqaba Castle Project 2006: Bulletin of the Council for British Research in the AL-DIMASHQI Levant I (2006), pp. 27-28.

1886 Kitāb nukhbat al-dahr fì 'ajāìb al-barr wa'l-bahr, transl. MichaEL MeHREN, Saint Petersburg 1866. 
EADIE, J.W.

1984 Humayma 1983. The Regional Survey: Annual of the Department of Antiquities of Jordan 28 (1984), pp. 211-224.

EADIE, J.W. - OLESON, J.P.

1986 The Water-Supply of Nabatean and Roman Humayma: Bulletin of the American School of Oriental Research 262 (1986), pp. 35-76.

ELAD, A.

1999 The Southern Golan in Early Muslim Period. The significance of two newly discovered milestones of 'Abd al-Malik: Der Islam LXXVI (1999), pp. 33-88.

AL-FAKHIRY, S.

2003 Al-Humayma: Reconstruction of the Nabatean Water Reservoir at al-Humayma:

FOOTE, M. R.

Munzajat IV (2003), p. 40

2007 From Residence to Revolutionary Headquarters: The Early Islamic Qasr and Mosque Complex at al-Humayma and its $8^{\text {th }}$-century Context: TH.E. LEVY - P.M.M. DAVIAU R.W. YounKer - M. SHAer (eds.), Crossing Jordan. North American Contributions to the Archaeology of Jordan, London - Oakville 2007, pp. 457-465.

GENEQUAND, D.

2006 Umayyad Castles; the Shift from Late Antique Military Architecture to Early Islamic Palatial Building: H. KenNEDy (ed.), Muslim Military Architecture in Greater Syria: from the coming of Islam to the Ottoman Period, Leiden 2006, pp. 3-25.

GHAWANMEH, Y.

1992 Earthquake effects on Bilad ash-Sham Settlements: M. ZAGHLOUL - K. 'AmR - F. ZAYADINE - R. NABEEL - R. TAWFiQ (eds.), Studies in the History and Archaeology of Jordan IV, Amman 1992, pp. 53-59.

GIL, M.

1997 A History of Palestine. 634-1099, Cambridge 1997.

GLUECK, N.

1939 Explorations in Eastern Palestine, III, New Haven 1939.

AL-HARAWI

1953 Kitāb az-Zyāāāt, transl. J. SOURDEL ThOMINe, Damascus 1953.

HAWTING, G.R.

2000 The First Dynasty of Islam. The Umayyad caliphate A.D. 661-750, London 2000.

HAYES, J.W.

1996 The Pottery: S.E. SIDEBOTHAM - W.Z. WENDRICH (eds.), Berenike '95. Preliminary Report of the 1995 Excavations at Berenike (Egyptian Red Sea Coast) and Survey of Eastern Desert, Leiden 1996, pp. 147-178.

JoHNS, J.

1995 The Longue Durée. State and Settlement Strategies in Southern Transjordan across the Islamic Centuries: E. Rogan - T. Tell (eds.), Village, Steppe and State. The Social Origins of Modern Jordan, London - New York 1995, pp. 1-31.

Jones, R. - TompSett, G. - Politis, K.D. - Photo-Jones, E.

2000 The TTawāhīn as-Sukkar and Khirbat ash-Shaykh 'Isa Project. Phase I: The Surveys: KENNEDY, $\mathrm{H}$. Annual of the Department of Antiquities of Jordan 34 (2000), pp. 523-534.

1992 The Impact of Muslim Rule on the Pattern of Rural Settlement in Syria: P.J. CANiVET - P. ReY-CoQuAis (eds.), La Syrie de Bysance à l'Islam, VII-VIII siècles: Actes du Colloque 
international Lyon-Maison de l'Orient Méditerranéen, Paris-Institut du Monde Arabe, 11-15 Septembre 1990, Damascus 1992, pp. 291-298.

2001 The Armies of the Caliphs. Military and Society in the Early Islamic State, London 2001.

2002 An Historical Atlas of Islam, Leiden 2002.

2004 The Prophet and the Age of the Caliphates: The Islamic Near East from the $6^{\text {th }}$ to $11^{\text {th }}$ century, Harlow $2004^{2}$.

2008 Inherited Cities: S.K. Jayyusi - R. Holod - A. PetruCCIOLI - A. RAYMond (eds.), The City in the Islamic World, Leiden 2008, pp. 93-114.

KENNEDY, H. - BEWLEY, R.

2004 Ancient Jordan from the Air, London 2004.

KING, G.

1985 A Survey of the Southern Ghawr, the Wadi 'Araba and Western Trans-Jordan, 1981-2: Proceedings of the Seminar for Arabian Studies XV (1985), pp. 41-47.

KNAUF, E.A. - BROOKER, C.H.

1988 Review of Rami G. Khouri - Donald Whitcomb, Aqaba. Port of Palestine on the China LAPIDUS, I.M. Sea, Amman 1988: Zeitschrift des Deutschen Palästina Vereins CIV (1988), pp. 179-181.

2002 A History of Islamic Societies, Cambridge 2002.

MAGNESS, J.

2003 The Archaeology of the Early Islamic Settlement in Palestine, Winona Lake 2003.

MCDONALD, B.

1980 The Wadi el Hasa Survey, 1979. A Preliminary Report: Annual of the Department of Antiquities of Jordan 24 (1980), pp. 169-183.

MelKaWi, A. - KhairieH, A. - Whitcomb, D.

1994 The Excavation of Two Seventh Century Pottery Kilns at Aqaba: Annual of the MiLLER, M. Department of Antiquities in Jordan 38 (1994), pp. 447-468.

$1991 \quad$ Archaeological Survey of the Kerak Plateau, Atlanta 1991.

MiLWRIGHT, M.

2008 The Fortress of the Raven. Karak in the Middle Islamic Period (1100-1650), Leiden 2008.

MusiL, A.

1934 The Northern Hejāz. A Topographical Itinerary, New York 1934.

NORTHEDGE, A.

1992 Studies on Roman and Islamic Amman. The excavation of Mrs C.M. Bennet and other investigations, Oxford 1992.

2004 Archaeology and New Urban Settlement in Early Islamic Syria and Iraq: G.R.D. KING - A. CAMERon (eds.), The Byzantine and Early Islamic Near East. Land Use and Settlement Patterns, II, Princeton 1994, pp. 231-265.

OLESON, J.P.

2001 King, Emperor, Priest, and Caliph: Cultural Change at Hawara (Ancient al-Humayma) in the First Millenium AD: G. BISHEH (ed.), Studies in the History and Archaeology of Jordan VII, Amman 2001, pp. 569-580.

2003 Preliminary Report of the al-Humayma Excavation Project, 2000, 2002: Annual of the Department of Antiquities of Jordan 47 (2003), pp. 37-64.

2010 Humayma Excavation Project, Final Report. The Site and the Water-Supply System, I, Boston 2010. 
PARKER, S.TH.

2002 The Roman 'Aqaba Project: The 2000 Campaign: Annual of the Department of Antiquities of Jordan 46 (2002), pp. 409-429.

2003 The Roman 'Aqaba Project: The 2002 Campaign: Annual of the Department of Antiquities of Jordan 47 (2003), pp. 321-333.

2006 History of the Roman Frontier East of the Dead Sea: S.Th. Parker, The Roman Frontier in Central Jordan: Final Report on the Limes Arabicus Project, 1980-1989 (Dumbarton Oaks Studies 40), Cambridge 2006, pp. 517-527.

2009 The Roman Port of Ayla and its Economic Hinterland: F. AL-HMOUD (ed.), Studies in the History and Archaeology of Jordan XI, Amman 2009, pp. 735-743.

Pedersen, R.K.

2000 Under the Erythraean Sea: An Ancient Shipwreck in Eritrea: Institute of Nautical Archaeology Quarterly XXVII (2000), pp. 3-13.

Petersen, A.

2005 The Towns of Palestine under Muslim Rule AD 600-1600, Oxford 2005.

RETZELEFF, A.

2003 A Nabatean and Roman Domestic Area at the Red Sea Port of Aila: Bulletin of the American School of Oriental Research 331 (2003), pp. 45-65.

Al-SALAh, M. - Al-AzZAWI, S.

1997 Effect of Natural Environment on the Development of al-Humayma and on the Abbasid Movement 68-132 AH (687-750 AD): G. BISHEH - M. ZAGHLOUL - I. KEgRBERG (eds.), Studies in the History and Archaeology of Jordan VI, Amman 1997, pp. 353-357.

SAVANE, S.H. - ZAMORA, K.A. - KelleR, D.R.

2003 Archaeology in Jordan, 2002 Season: American Journal of Archaeology 107 (2003), pp. 449-475.

SCHICK, R.

1995 Christianity at Humayma, Jordan: Liber Annuus XLV (1995), pp. 319-342.

1997 Southern Jordan in the Fatimid and Seljuq Periods: Bulletin of the American School of Oriental Research 305 (1997), pp. 73-85.

1998 Archaeological Sources for the History of Palestine: Palestine in the Early Islamic Period: Luxuriant Legacy: Near Eastern Archaeology 61/2 (1998), pp. 74-108.

2007 al-Humayma and the Abbasid Family: F. AL-KHRAYsheH (ed.), Studies in the History and SHARON, M Archaeology of Jordan IX, Amman 2007, pp. 345-355.

1966 An Arabic Inscription from the Time of the Caliph 'Abd al-Malik: Bulletin of the School of Oriental and African Studies 20 (1966), pp. 367-372.

SHDAIFAT, Y.M. - TATWNE, K. - BEN BADHANN, Z.N.

2006 Mu'tah University Excavations at Shuqayra al-Gharbiyya: Preliminary Report on the 2005 Season: Annual of the Department of Antiquities of Jordan 50 (2006), pp. 208-211.

SHDAIFAT, Y.M. - BEN BADHANN, Z.N.

2008 Shuqayra al-Gharbiyya: A New Early Islamic Compound in Central Jordan: Near Eastern Archaeology 71 (2008), pp. 186-188.

SMITH, A.M. - NIEMI, T.M.

1994 Short Report on the 1996 Season of the Southeast Araba Archaeological Survey: Annual of the Department of Antiquities of Jordan 38 (1994), pp. 469-483.

SMITH, A.M. - STEVENS, M. - NiEMI, T.M.

1997 The Southeast Arab Archaeological Survey: A Preliminary Report of the 1994 Season: Bulletin of the American School of Oriental Research 305 (1997), pp. 45-71. 
AL-ṬABARI

1879-1901 Tārikh ar-rasul wa-mūluk, transl. M. J. DE GOEJE, Leiden 1879-1901.

WALMSLEY, A.

2000 Production, exchange and regional trade in the Islamic east Mediterranean: old structures, new systems?: I. HANSEN - C. WICKHAM (eds.), The Long Eighth Century, Leiden 2000, pp. 265-343.

2007 Early Islamic Syria. An Archaeological Assessment, London 2007.

WALMSLEY, A. - KARSGAARD, K. - GREY, T.

1999 Town and Village: Site Transformations in South Jordan (The Gharandal Archaeological Project, Second Season Report): Annual of the Department of Antiquities in Jordan 43 WHEATLEY, $\mathrm{P}$. (1999), pp. 459-478.

2001 The Places Where Men Pray Together, Chicago 2001.

WHITCOMB, D.

1989 Evidence of the Umayyad Period from the Aqaba Excavations: M.A. BAKHIT - R. ScHICK (eds.), The Fourth International Conference on the History of the Bilād al-Shäm during the Umayyad Period, Amman 1989, pp. 164-184.

1990 Diocletian's misr at 'Aqaba: Zeitschrift des Deutschen Palästina-Vereins 106 (1990), pp. 156-161.

1994a Ayla. Art and Industry in the Islamic Port of Aqaba, Chicago 1994.

1994b The Misr of Ayla: Settlement at al-Aqaba in the Early Islamic Period: G.R.D. KING - A. CAMERON (eds.), The Byzantine and the Early Islamic Near East. Land use and settlement patterns, II, Princeton 1994, pp. 156-160.

1995 Toward a Common Denominator: An Archaeological Response to M. Morony on Pottery and Urban Identities: I. BIERMAN (ed.), Identity and Material Culture in the Early Islamic World, Chicago 1995, pp. 47-68.

2000 Excavations in Aqaba, Jordan, and a model of the early Islamic city: Adumatu I (2000), pp. 62-65.

2006a The Walls of Early Islamic Ayla: Defence or Symbol?: H. KenNEDY (ed.), Muslim Military Architecture in Greater Syria. From the Coming of Islam to the Ottoman Period, Boston 2006, pp. 61-74.

2006b Land Behind Aqaba: The Wadi 'Arabah During the Early Islamic Period: P. BIENKOwsKI - K. Galor (eds.), Crossing the Rift: Resources, Routes, Settlement Patterns and Interaction in the Wadi 'Arabah, Oxford 2006, pp. 239-242.

2007 An Urban Structure for the Early Islamic City: An Archaeological Hypothesis: A.K. Bennison - A.L. Gascoigne (eds.), Cities in the Pre-Modern Islamic World. The Urban Impact of Religion, State and Society, New York 2007, pp. 15-26.

2009 Ayla at the Millenium: Archaeology and History: F. AL-KHRAYsheH (ed.), Studies in the History and Archaeology of Jordan X, Amman 2009, pp. 123-132.

2010 Ayla at the Millennium: Archaeology and History: Annual of the Department of Antiquities of Jordan LIV (2010), pp. 167-176.

WILDING, R.F.

1989 The Pottery: S.H.C. Munroy-Hay (ed.), Excavations at Aksum: an Account of Research at the Ancient Ethiopian Capital Directed in 1972-74 by the Late Dr. Neville Chittick, London 1989, pp. 235-316.

WILLELMI TYRENSIS

1976 A History of Deeds done beyond the Sea, transl. E.A. BABCOCK - A.C. KREY, luogo 1976, vol. I, pp. 506-507. 
AL-YA'QŪBĪ

1892 Kitāb al-buldān, transl. M. J. DE GOEJE, Leiden 1892.

YĀQŪT AL-HAMAWİ

1866-1873 Mu’jam al-buldān, transl. F. WÜSTENFELD, 6 vols., Leipzig 1866-1873. 


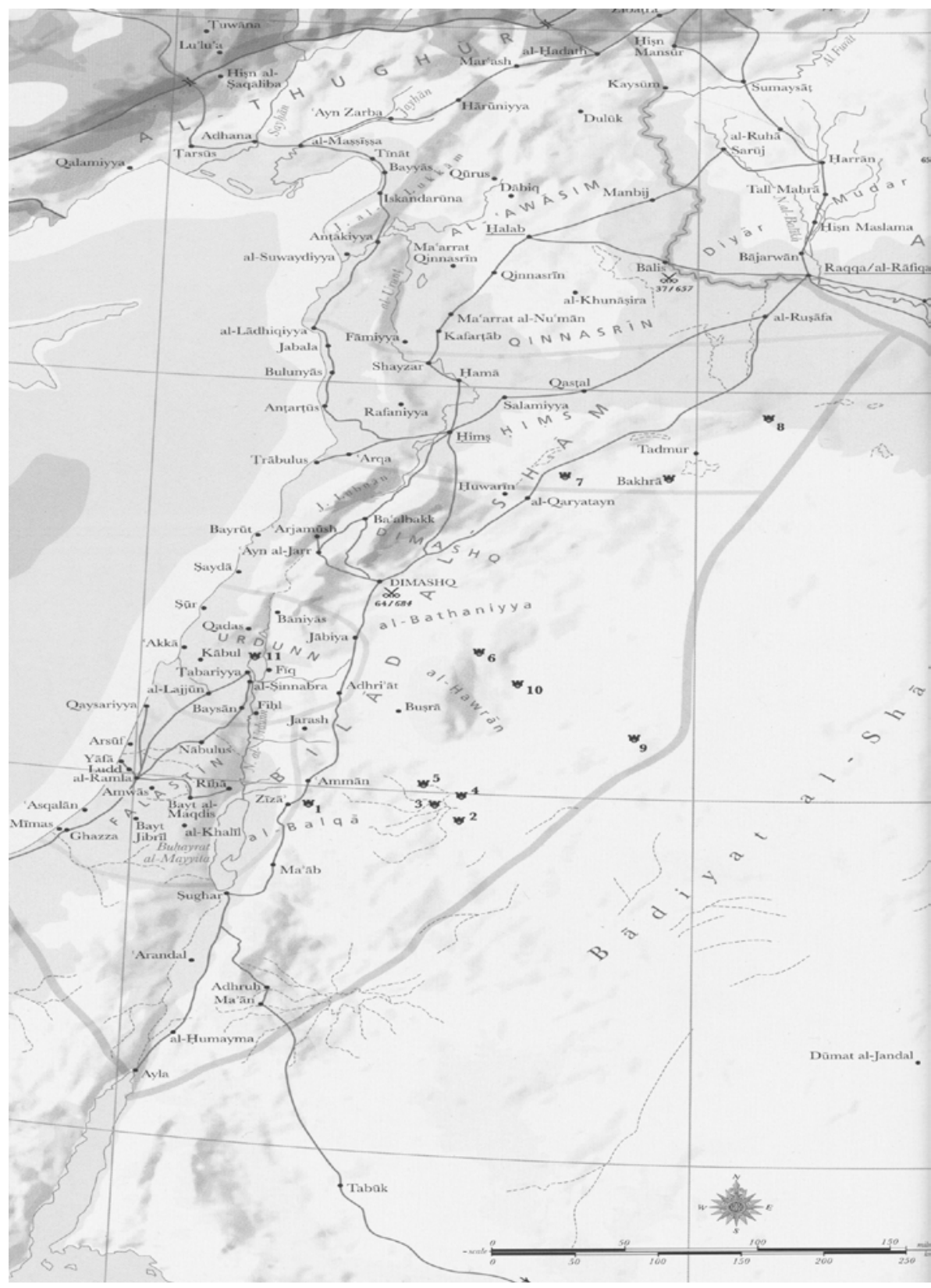

Fig. 1 - Map of the Early Islamic Bilād al-Shām (after Kennedy 2002, fig. 1). 

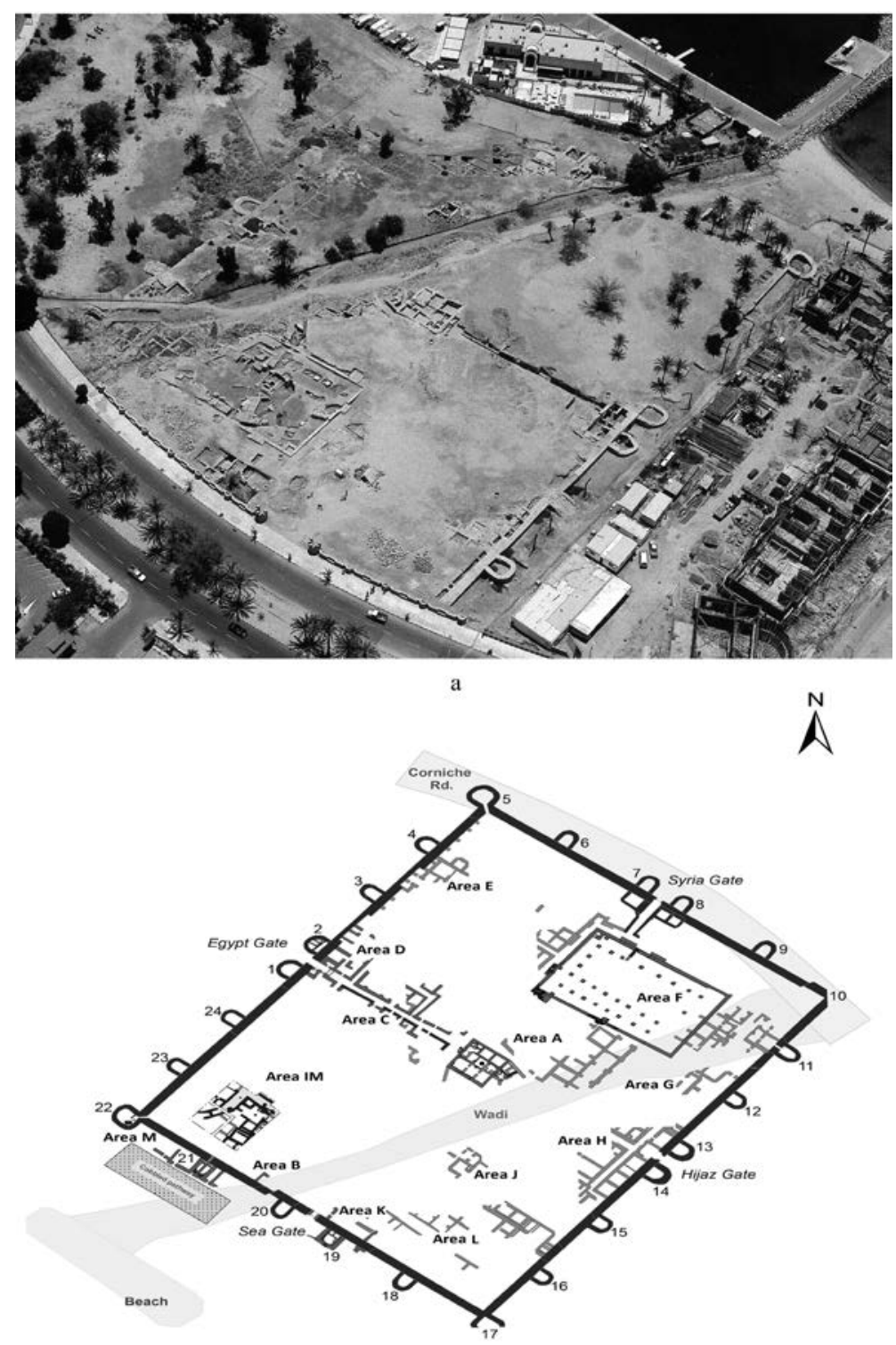

$\tilde{\Lambda}$

b

Fig. 2 - a. Early Islamic Ayla excavations, panorama looking south east (after Kennedy Bewly 2004, fig. 12.8A). b. Early Islamic Ayla, GIS-based plan (after Damgaard 2011, fig. 2). 


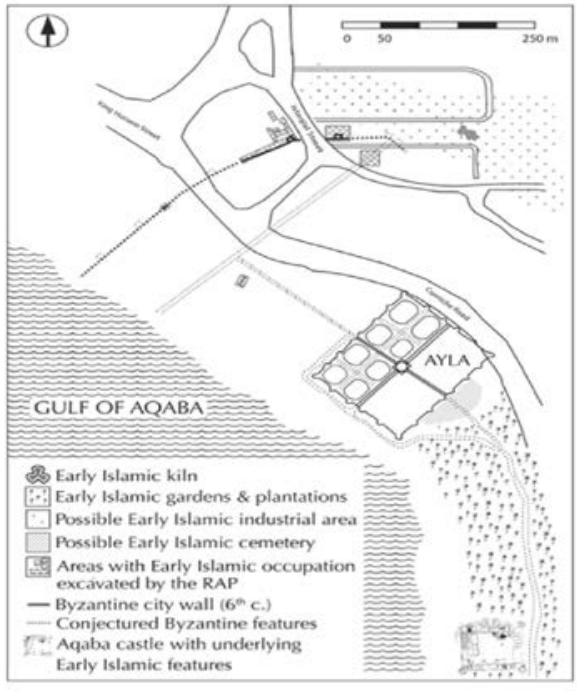

a

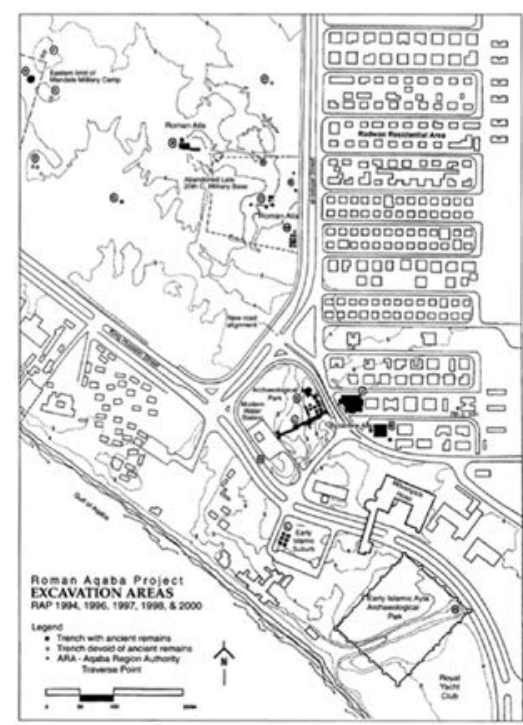

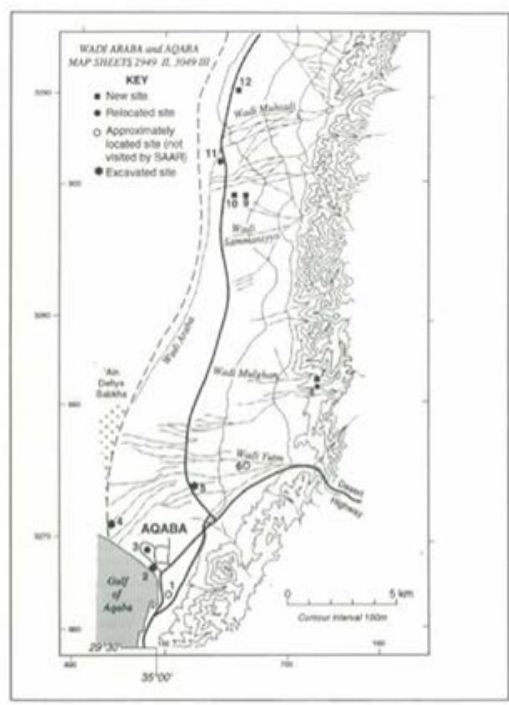

Fig. 3 - a. Graphic reconstruction of Ayla and its suburbs (after Damgaard 2009, fig. 10.2); b. Plan of the excavation areas of the Roman Aqaba Project from 1994 to 2000 (after Retzleff 2003, fig. 1); c. Map of 1994 surveys in the Wadi 'Araba (after Smith - Niemi 1994, fig. 2). 


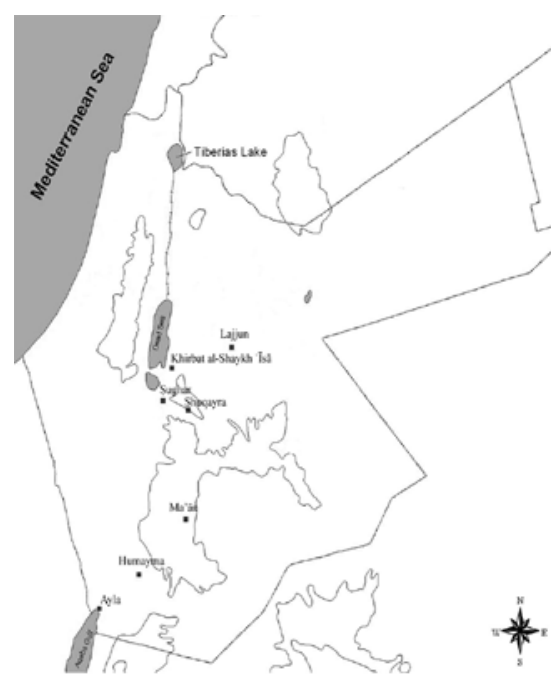

a

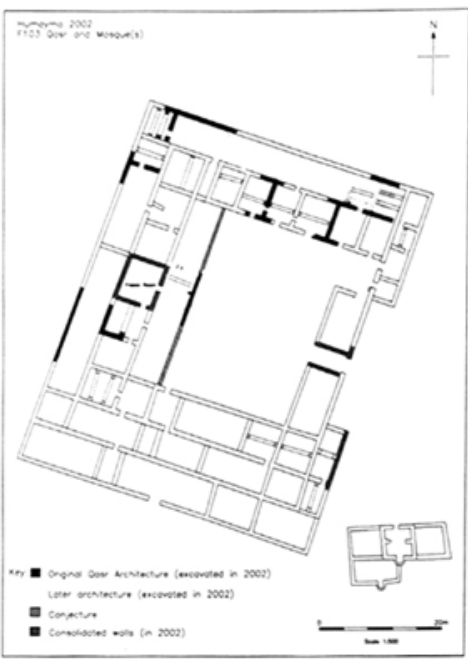

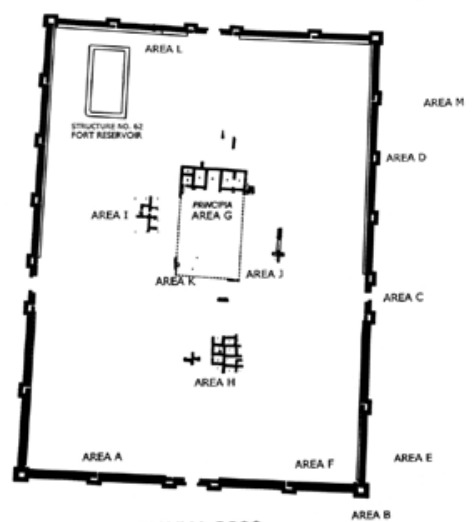

HUMAYMA 2000

E116 ROMAN FORT

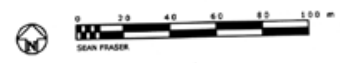

b

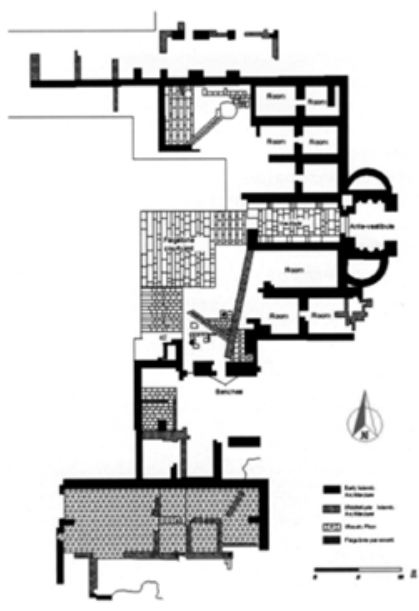

d

Fig. 4 - a. Early Islamic settlements here mentioned on GIS base Map: Stamen Toner/OSM; b. Humayma castrum plan (after Oleson 2003, fig. 2); c. Humayma, plan of the qașr and the Abbasid mosque of Humayma (after Oleson 2001, fig. 8); d. Shuqayra, plan of the areas excavated by the University of Mu'ta (after Shdaifat - Ben Badhann 2008, fig. 1). 